\author{
V.D. Moskaliuk, T.R. Kolotylo
}

\title{
CHARACTERISTICS OF SOME IMMUNOLOGICAL INDICATORS OF HIV INFECTION IN COMBINATION WITH TUBERCULOSIS
}

\author{
Bukovynian State Medical University
}

The purpose of the work is to carry out a comparative analysis of epidemiological, clinical and individual laboratory parameters of groups of patients with HIV infection associated with tuberculosis (TB) and TB monoinfection.

Patients and methods. A comprehensive immunological examination was performed on 231 patients, including 155 HIV-infected with active newly diagnosed tuberculosis and 76 on tuberculosis alone. The HIV/TB group was divided into 3 subgroups depending on the time of TB accession to HIV infection.

The levels of interleukin-4 (IL-4) and interferon-y (IFN-y) were compared for groups with co-infection with HIV/TB and patients with TB monoinfection.

Results. In associated HIV/TB infection, the level of $C D 4^{+}$T-lymphocytes is significantly lower compared to patients with TB monoinfection.

In the HIV/TB group, it was established the presence of a medium feedback force between the number of $C D 4^{+} T$ lymphocytes and the serum concentration of IFN-y (correlation coefficient $r=-0.36$, confidence level $P<0.05$ ); weak direct relationship between viral load and serum IFN-y concentration ( $r=0.25, P<0.05)$; medium strength inverse relationship between the number of $C D 4^{+} T$-lymphocytes and the level of viral load $(r=-0.44, P<0.01)$. In the group with TB monoinfection, no correlation was found between the number of $C D 4^{+} T$-lymphocytes and cytokine parameters.

Conclusions. In associated HIV/TB infection, $C D 4^{+} T$ lymphocyte counts are significantly lower than in patients with TB only.

As HIV infection progresses (decrease in $C D 4^{+} T$ lymphocytes and increase in HIV load), there is an increase in serum IFN-y and IL-4, which probably indicates a decrease in the number of anti-inflammatory T-regulatory cells, or a decrease in their suppressor activity.

Key words: HIV infection; tuberculosis; $C D 4^{+} T$ lymphocytes; interleukin-4; interferon-y; cytokines.

Immunological links in the pathogenesis of tuberculosis and HIV infection are very complex and insufficiently studied. Reducing the number of $\mathrm{CD} 4^{+}$T-lymphocytes in
HIV infection significantly increases susceptibility to tuberculosis infection or reactivation of initially latent tuberculosis infection [1].

In addition, foreign authors point to the important role of cytokines in the pathogenesis of HIV infection. Such studies in the combined pathology of HIV/TB in the domestic literature is quite small, and foreign studies are usually very controversial $[2,3]$. Thus, some authors claim that the peripheral blood cells of patients with dual infection produce a greater number of IL-4, IL-8 than patients with tuberculosis or HIV monoinfection, which contributes to the rapid reproduction of HIV [4]. Other authors point out that in HIVassociated tuberculosis, the level of both Th-1 and Th-2 cytokines is suppressed [5].

The purpose of the work - to carry out a comparative comprehensive immunological examination of HIV-infected and immunocompetent patients with active tuberculosis.

\section{Patients and methods}

231 persons were examined - $184(79.7 \%)$ men and 47 (20.3\%) women aged 23 to 60 years. The mean age was (38.8 \pm 1.2$)$ years.

All patients were subjected to a comprehensive laboratory examination and divided into the following groups.

I. Uninfected HIV (immunocompetent) individuals with active newly diagnosed tuberculosis -76 patients (TB group).

II. HIV-infected with active newly diagnosed tuberculosis - 155 patients (HIV/TB group). Within the group of HIV/TB, 3 subgroups were identified depending on the time of $T B$ accession to HIV infection:

Subgroup 1 - HIV-infected, in which at different stages of HIV infection (primary disease) was detected TB - 72 patients;

Subgroup 2 - persons in whom for several years prior to the registered HIV infection and the time of hypothetical infection (according to the epidemiological history) TB was diagnosed, that is, the primary disease was TB -26 people;

Subgroup 3 - HIV-infected, in which the disease was registered at about the same time and it was impossible to determine which disease was primary -57 people. 
We compared CD4 ${ }^{+}$T-lymphocyte counts, levels of IL-4, IFN-y for groups with combined HIV/TB infection and patients with TB monoinfection. Immune status was studied in a group of HIV/TB patients within 3-6 months from the time of diagnosis of the associated infection.

Statistical processing of the results of the study was performed using Windows, Word and Excel software; STATISTICA 6.0 using the method of variation statistics with the determination of reliability using Student's test, and when the number of observations is less than 20 used the nonparametric method of Wilcoxon for independent populations, or Kraskel-Wallis analysis of variance. The MannWhitney $U$ test was used to compare the two independent groups [6]. Differences were considered statistically significant at $\mathrm{P}<0.05$. Spearman's rank method was used for correlation analysis [7].

\section{Research results and their discussion}

The average number of $\mathrm{CD} 4^{+} \mathrm{T}$-lymphocytes was significantly lower in the group of HIV/TB - (389.1 \pm 24.5$)$ cells $/ \mathrm{mm}^{3}$ than in patients with TB alone $-(542.2 \pm 27.4)$ cells $/ \mathrm{mm}^{3}(\mathrm{P}<0.001)$.

When comparing $\mathrm{CD} 4^{+} \mathrm{T}$-lymphocytes in patients with primary TB with combined infection in three subgroups depending on the time of TB accession, it can be noted that the patterns characteristic of the whole group of HIV/TB can be traced for all three subgroups compared to monoinfection $(\mathrm{P}<0,05-0.01)$.

For caseous pneumonia, spontaneous production of IL-4 was higher $-\left(7.1 \pm 1.0 \mathrm{pg} / \mathrm{ml} / 10^{6}\right)$ in the group of HIVI TB compared with TB monoinfection - (3.2 \pm 0.6$) \mathrm{pg} / \mathrm{ml} / 10^{6}$ $(\mathrm{P}<0.05)$, and spontaneous production of IFN-Y also exceeded the corresponding figure in patients with TB only - (90.7 \pm 32.6$) \mathrm{pg} / \mathrm{ml} / 10^{6}$ against $(7.3 \pm 1.1) \mathrm{pg} / \mathrm{ml} / 10^{6}$ $(\mathrm{P}<0.001)$.

The results of the study of the level of cytokines - serum concentration and spontaneous production of IL-4, IFN-y in the groups of HIV/TB and patients with TB only were analyzed. Simultaneously with the study of cytokine levels, the load of HIV in patients with various forms of TB was also determined.

Differences were observed in different forms of TB. Thus, in focal TB, the serum concentration of IL-4 was higher in combined HIV/TB infection than in TB monoinfection (2.8 \pm 1.2$) \mathrm{pg} / \mathrm{ml}$ against $(1.5 \pm 0.2) \mathrm{pg} / \mathrm{ml}(\mathrm{P}<0.05)$, and the serum concentration of IFN-y is lower $-(24.2 \pm 8.9) \mathrm{pg} / \mathrm{ml}$ against $(50.6 \pm 9.4) \mathrm{pg} / \mathrm{ml}(\mathrm{P}<0.05)$. The viral load $(\mathrm{VL})$ of HIV was the lowest - (33115 \pm 9896 copies/ml, Table 3$)$.

In infiltrative TB in the group with combined infection, the serum concentration of IL-4 was significantly higher than in TB monoinfection - (3.8 \pm 0.7$) \mathrm{pg} / \mathrm{ml}$ against $(1.5 \pm 0.3) \mathrm{pg} /$ $\mathrm{ml}(\mathrm{P}<0.05)$. The viral load was quite high $-(201834 \pm 53984)$ copies/ml (high VL is considered at the level of $>100$ thousand copies/ml).

In the case of FCT, the level of serum concentration of IL-4 in the HIV/TB group was (3.2 \pm 0.9$) \mathrm{pg} / \mathrm{ml}$, which significantly exceeded this figure in patients with TB only - $(1.5 \pm 0.3) \mathrm{pg} / \mathrm{ml}(P<0.05)$, and the serum concentration of IFN-y was also significantly higher - $(177.6 \pm 40.2) \mathrm{pg} / \mathrm{ml}$ against $(14.6 \pm 2.7) \mathrm{pg} / \mathrm{ml}(\mathrm{P}<0.001)$. HIV VL remained moderately elevated $-(94880 \pm 18472)$ copies/min.

For disseminated TB, there were no significant differences in the level of IL-4 in the compared groups. But the spontaneous production of IFN-y in patients with associated infection was (16.9 \pm 3.4$) \mathrm{pg} / \mathrm{ml} / 10^{6}$, which significantly exceeded this figure in TB monoinfection (4.2 \pm 0.7$) \mathrm{pg} / \mathrm{ml} / 10^{6}(\mathrm{P}<0.001)$. The viral load of HIV was registered at a very high level - (635262 \pm 147254$)$ copies $/ \mathrm{ml}$.

In generalized TB, serum concentrations of IL-4 and IFN-y were statistically significantly higher in the group of

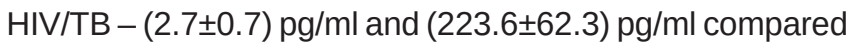
with monoinfection $-(1.2 \pm 0.2) \mathrm{pg} / \mathrm{ml}$ and $(18.8 \pm 3.0) \mathrm{pg} / \mathrm{ml}$, respectively $(P<0.05$ and $P<0.001$, respectively). Spontaneous production of IFN-y in all HIV/TB patients was not determined, and in patients with TB monoinfection remained low $-(4.6 \pm 0.8) \mathrm{pg} / \mathrm{ml}$. Viral load was recorded at the highest level - (963482 \pm 92114$)$ copies $/ \mathrm{ml}$.

For extrapulmonary TB, significant differences were found between the group of HIV/TB and TB monoinfection by the level of serum concentration of IFN-y - its level was significantly higher in the group of HIV/TB - (286.1 \pm 70.8$)$ $\mathrm{pg} / \mathrm{ml}$ compared with the group of patients only on TB (71.7 \pm 8.2$) \mathrm{pg} / \mathrm{ml}(\mathrm{P}<0.001)$. HIV viral load was also very high in this form of combined TB - (726130 \pm 99183$)$ copies $/ \mathrm{ml}$.

In general, the levels of IL-4 in both serum and spontaneous production showed only a tendency to increase in the HIV/TB group, compared with the group of patients with TB only. Serum IFN-y concentration was significantly higher in the HIV/TB group than in TB monoinfection - $(168.6 \pm 41.7) \mathrm{pg} / \mathrm{ml}$ versus $(79.4 \pm 15.3) \mathrm{pg} /$ $\mathrm{ml}$, respectively $(\mathrm{P}<0.05)$.

During the correlation analysis of the obtained data on the level of cytokines, CD4+T-lymphocytes, viral load (used Pearsen's parametric analysis and non-parametric Spearman's) in the group of HIV/TB found the presence of: - the average feedback between the number of CD4 ${ }^{+} \mathrm{T}$ lymphocytes and the serum concentration of IFN-y (correlation coefficient $r=-0.36$, confidence level $P<0.05$ );

- the average strength of the inverse relationship between the number of $C D 4^{+} T$-lymphocytes and the level of viral load $(r=-0.44, P<0.01)$.

In the group with TB monoinfection, no correlation was found between the number of $C D 4^{+} T$ lymphocytes and cytokine parameters. 
Table 1

Levels of IL-4, IFN-y and VL (for HIV +) in the HIV/TB and TB groups depending on the form of tuberculosis

\begin{tabular}{|c|c|c|c|c|c|c|c|c|c|}
\hline \multirow{4}{*}{ Form of TB } & \multicolumn{5}{|c|}{ HIV/TB, n=155 } & \multicolumn{4}{|c|}{ TB monoinfection, $\mathrm{n}=76$} \\
\hline & \multicolumn{2}{|c|}{ IL-4 } & \multicolumn{2}{|c|}{ IFN-y } & \multirow{3}{*}{ VL, copies/ml } & \multicolumn{2}{|c|}{ IL-4 } & \multicolumn{2}{|c|}{ IFN-y } \\
\hline & $\begin{array}{l}\text { serum, } \\
\mathrm{pg} / \mathrm{ml}\end{array}$ & $\begin{array}{l}\text { spont., } \\
\mathrm{pg} / \mathrm{ml} / 10^{6}\end{array}$ & $\begin{array}{l}\text { serum, } \\
\mathrm{pg} / \mathrm{ml}\end{array}$ & $\begin{array}{l}\text { spont., } \\
\mathrm{pg} / \mathrm{ml} / 10^{6}\end{array}$ & & $\begin{array}{c}\text { serum, } \\
\mathrm{pg} / \mathrm{ml}\end{array}$ & $\begin{array}{l}\text { spont., } \\
\mathrm{pg} / \mathrm{ml} / 10^{6}\end{array}$ & $\begin{array}{l}\text { serum, } \\
\mathrm{pg} / \mathrm{ml}\end{array}$ & $\begin{array}{l}\text { spont., } \\
\mathrm{pg} / \mathrm{ml} / 10^{6}\end{array}$ \\
\hline & $1-1$ & $1-2$ & $1-3$ & $1-4$ & & $2-1$ & $2-2$ & $2-3$ & $2-4$ \\
\hline 1. Focal & $2.8 \pm 1.2^{2-1}$ & $14.5 \pm 6.3$ & $\begin{array}{l}24.2 \pm \\
8.9^{2-3}\end{array}$ & 0 & $\begin{array}{c}33115 \pm 9896 \\
2,3,4,5,6,7\end{array}$ & $\begin{array}{l}1.5 \pm \\
0.2^{1-1}\end{array}$ & $12.8 \pm 7.2$ & $\begin{array}{l}50.6 \pm \\
9.4^{1-3}\end{array}$ & $\begin{array}{l}41.7 \pm \\
10.4\end{array}$ \\
\hline $\mathrm{n}$ & \multicolumn{5}{|c|}{24} & \multicolumn{4}{|c|}{8} \\
\hline 2. Infiltrative & $3.8 \pm 0.7^{2-1}$ & $3.6 \pm 0.4$ & $\begin{array}{c}137.7 \pm \\
29.8\end{array}$ & $\begin{array}{l}93.9 \pm \\
24.5\end{array}$ & $\begin{array}{c}201834 \pm 53984 \\
1,3,4,5,6,7\end{array}$ & $\begin{array}{l}1.5 \pm \\
0.3^{1-1}\end{array}$ & $3.4 \pm 0.4$ & $\begin{array}{c}111.6 \pm \\
21.1\end{array}$ & $\begin{array}{c}123.6 \pm \\
14.7\end{array}$ \\
\hline $\mathrm{n}$ & \multicolumn{5}{|c|}{49} & \multicolumn{4}{|c|}{14} \\
\hline $\begin{array}{l}\text { 3. Caseous } \\
\text { pneumonia }\end{array}$ & $1.7 \pm 0.4$ & $7.1 \pm 1.0^{2-2}$ & $\begin{array}{c}204.5 \pm \\
58.4\end{array}$ & $\begin{array}{l}90.7 \pm \\
32.6^{2-4}\end{array}$ & $\begin{array}{c}92450 \pm 22890 \\
1,2,5,6,7\end{array}$ & $1.4 \pm 0.4$ & $3.2 \pm 0.6^{1-2}$ & $\begin{array}{c}183.7 \pm \\
42.9\end{array}$ & $\begin{array}{l}7.3 \pm \\
1.1^{1-4}\end{array}$ \\
\hline $\mathrm{n}$ & \multicolumn{5}{|c|}{18} & \multicolumn{4}{|c|}{6} \\
\hline 4. FCT & $3.2 \pm 0.9^{2-1}$ & $3.7 \pm 0.8$ & $\begin{array}{l}177.6 \pm \\
40.2^{2-3}\end{array}$ & $6.7 \pm 1.9$ & $\begin{array}{c}94880 \pm 18472 \\
1,2,5,6,7\end{array}$ & $\begin{array}{l}1.5 \pm \\
0.3^{1-1}\end{array}$ & $3.5 \pm 0.7$ & $\begin{array}{l}14.6 \pm \\
2.7^{1-3}\end{array}$ & $\begin{array}{c}8.2 \pm \\
2.0\end{array}$ \\
\hline $\mathrm{n}$ & \multicolumn{5}{|c|}{6} & \multicolumn{4}{|c|}{12} \\
\hline 5. Disseminated & $1.8 \pm 0.5$ & $4.1 \pm 0.9$ & $\begin{array}{c}126.5 \pm \\
21.3\end{array}$ & $\begin{array}{l}16.9 \pm \\
3.4^{2-4}\end{array}$ & $\begin{array}{c}635262 \pm 147254 \\
1,2,3,4\end{array}$ & $\begin{array}{c}1.6 \pm \\
0.2\end{array}$ & $3.9 \pm 0.7$ & $\begin{array}{c}104.8 \pm \\
19.5\end{array}$ & $\begin{array}{l}4.2 \pm \\
0.7^{1-4}\end{array}$ \\
\hline $\mathrm{n}$ & \multicolumn{5}{|c|}{28} & \multicolumn{4}{|c|}{14} \\
\hline 6. Generalized & $2.7 \pm 0.7^{2-1}$ & $2.8 \pm 0.9$ & $\begin{array}{l}223.6 \pm \\
62.3^{2-3}\end{array}$ & 0 & $\begin{array}{c}963482 \pm 92114 \\
1,2,3,4\end{array}$ & $\begin{array}{l}1.2 \pm \\
0.2^{1-1}\end{array}$ & $3.2 \pm 1.0$ & $\begin{array}{l}18.8 \pm \\
3.0^{1-3}\end{array}$ & $\begin{array}{c}4.6 \pm \\
0.8\end{array}$ \\
\hline $\mathrm{n}$ & \multicolumn{5}{|c|}{11} & \multicolumn{4}{|c|}{4} \\
\hline 7. Extrapulmonary & $1.8 \pm 0.3$ & $3.2 \pm 0.8$ & $\begin{array}{l}286.1 \pm \\
70.8^{2-3}\end{array}$ & $24.4 \pm 6.3$ & $\begin{array}{c}726130 \pm 99183 \\
1,2,3,4\end{array}$ & $2.1 \pm 0.5$ & $5.1 \pm 1.9$ & $\begin{array}{l}71.7 \pm \\
8.2^{1-3}\end{array}$ & $\begin{array}{c}19.8 \pm \\
5.2\end{array}$ \\
\hline $\mathrm{n}$ & \multicolumn{5}{|c|}{19} & \multicolumn{4}{|c|}{18} \\
\hline Together & $2.5 \pm 0.6$ & $5.6 \pm 1.6$ & $\begin{array}{l}168.6 \pm \\
41.7^{2-3}\end{array}$ & $33.2 \pm 9.8$ & $392450 \pm 63399$ & $1.5 \pm 0.3$ & $5.0 \pm 1.8$ & $\begin{array}{l}79.4 \pm \\
15.3^{1-3}\end{array}$ & $29.9 \pm 5.0$ \\
\hline
\end{tabular}

Note. The superscript numbers in the VL column indicate a significant difference $(P<0.001)$ between the forms of TB indicated by the numbers from 1 to 7 .

\section{Conclusions}

1. In associated HIV/TB infection, CD4 ${ }^{+}$T-lymphocyte counts are significantly lower compared to patients with TB monoinfection.

2. As HIV infection progresses (decrease in $C D 4^{+} T-$ lymphocytes and increase in HIV load), there is an increase in serum IFN-y and IL-4, which probably indicates a decrease in the number of anti-inflammatory T-regulatory cells, or a decrease in their suppressive activity.

3. Signs of progression of combined HIV/TB infection should be considered a rapid decrease in the number of $C D 4^{+} T$ lymphocytes, an increase in the load of HIV, an increase in serum IL-4 and IFN-y. 


\section{ОРИГІНАЛЬНІ ДОСЛІДЖЕННЯ}

\section{List of literature}

1. Москалюк В.Д., Колотило Т.Р., Баланюк І.В., Андрущак М.О Спосіб дослідження ВІЛ-інсекції, асоційованої з туберкульозом. - Пат. 143425. Укр.; заяв. 04.03.20; опуб. 27.07.20, Бюл. № 14.

2. Tuberculosis infection and disease in people living with HIV in countries with low tuberculosis incidence / J. Winter, A. Adamu, R. Gupta [et al.] // The International Journal of Tuberculosis and Lung Disease. - 2018. - N 22 (7). - P. 713-722.

3. Nann P. The global approach to struggle against a HIV-the associated tuberculosis / P. Nann // Problems of a tuberculosis. -2005. - N 2. - P. 13-16.

4. Ngadaya E.S. Delay in tuberculosis case detection in Pwani region, Tanzania. A cross sectional study / E. S. Ngadaya, G. S. Mfi- nanga, E. R. Wandwalo, O. Morkve // BMC Health Serv. Res. - 2014. - N 29 (1). - P. 196.

5. Tuberculosis co-infection in HIV infected persons of Kathmandu / G. P. Dhungana, P. Ghimire, S. Sharma, B.P. Rijal // Nepal. Med. Coll. J. - 2015. - N 10 (2). - P. 96-99.

6. Gordin F. M. Influence of a human infection of a virus of an immunodeficiency on a resistant tuberculosis to medical products / F. M. Gordin, J. P. Matts // Am. J. Respir. Cell. Mol. Biol. - 2016. - N 154. - P. 1478-1483.

7. Panteleev A. M. Extrapulmonary tuberculosis in HIV-infected. Socially significant infections / A. M. Panteleev, A. Savinat, Yu. Suprun // Tez. Reports Scientific-practical Conf. - 2015. - P. 35-36.

\section{References}

1. Moskaliuk, V.D., Kolotylo, T.R., Balaniuk, I.V., \& Andrushchak, M.O. (2020). Patent UA 143425 Ukraine (utility model) G01N 33/50 (2006.01) A method of studying HIV infection associated with tuberculosis. Bulleten, 14 [in Ukrainian].

2. Winter, J., Adamu, A., Gupta, R., Stagg, H., Delpech, V., \& Abubakar, I. (2018). Tuberculosis infection and disease in people living with HIV in countries with low tuberculosis incidence. The International Journal of Tuberculosis and Lung Disease, 22 (7), 713-722.

3. Nann, P. (2005). The global approach to struggle against a HIV-the associated tuberculosis. Problems of a Tuberculosis, 2, 13-16.

4. Ngadaya, E.S., Mfinanga, G.S., Wandwalo, E.R., \& Morkve, O. (2014). Delay in Tuberculosis case detection in Pwani region, Tanzania. A cross sectional study. BMC Health Serv., 29 (1), 196.

\section{ХАРАКТЕРИСТИКА ДЕЯКИХ ІМУНОЛОГІЧНИХ ПОКАЗНИКІВ ВІЛ-ІНФЕКЦІї В ПОЄДНАННІ 3 ТУБЕРКУЛЬОЗОМ}

В.Д. Москалюк, Т.Р. Колотило

Буковинський державний медичний університет

РЕЗЮМЕ. Мета роботи - здійснити порівняльний аналіз епідеміологічних, клінічних та окремих лабораторних показників груп хворих на ВІЛ-інсрекцію, поєднану з туберкульозом (ТБ), і ТБ-моноінфекцію. Пацієнти і методи. Здійснили комплексне імунологічне обстеження 231 хворого, зокрема 155 ВІЛінфрікованих з активним уперше виявленим туберкульозом та 76 тільки на туберкульоз. Групу ВІЛ/ ТБ поділили на 3 підгрупи залежно від часу приєднання ТБ до ВІЛ-інфекції.
5. Dhungana, G.P., Ghimire, P., Sharma, S., \& Rijal, B.P. (2015). Tuberculosis co-infection in HIV infected persons of Kathmandu. Nepal. Med. Coll. J., 10 (2), 96-99.

6. Gordin, F.M., Matts, J.P. (2016). Influence of a human infection of a virus of an immunodeficiency on a resistant tuberculosis to medical products. Am. J. Respir. Cell. Mol. Biol., 154, 1478-1483.

7. Panteleev, A.M., Savinat, A., \& Suprun, Yu. (2015). Extrapulmonary tuberculosis in HIV-infected. Socially significant infections. Tez. Reports Scientific-practical Conf., 35-36.
Порівняли рівні інтерлейкіну-4 (ІЛ-4) ma інтерферону-у (ІФН-у) для груп з поєднаною інфрекцією ВІЛ/ТБ і хворих на ТБ-моноінфекцію.

Результати. При асоційованій ВІЛ/ТБ-інфекції рівень $C D 4^{+} T$-лімфоцитів достовірно нижчий, порівняно з хворими на ТБ-моноінфекцію.

У групі ВІЛ/ТБ встановлена наявність середньої сили зворотного зв'язку між кількістю $C D 4^{+} T$ лімфоцитів і сироватковою концентрацією ІФН-у (коефріцієнт кореляції $r=-0,36$, рівень достовірності $P<0,05)$; слабкого прямого зв'язку між рівнем вірусного навантаження і сироватковою концентрацією ІФН-у (r=0,25, P<0,05); середньої сили зворотна залежність між кількістю $C D 4^{+} T$-лімфроцитів і рівнем вірусного навантаження $(r=-0,44, P<0,01)$. У групі з ТБ-моноінфекцією кореляції між кількістю 


\section{ОРИГІНАЛЬНІ ДОСЛІДЖЕННЯ}

$C D 4^{+} T$-лімфоцитів і цитокіновими показниками не виявлено.

Висновки. При асоційованій ВІЛ/ТБ-інфекції показники $C D 4^{+} T$-лімфроцитів достовірно нижчі, порівняно з хворими на ТБ-моноінфекцію.

У міру прогресування ВІЛ-інфрекції (зниження кількості $C D 4^{+} T$-лімфоцитів і наростання навантаження ВІЛ) спостерігається збільшення сироваткового вмісту ІФН-у та ІЛ-4, що, ймовірно, свідчить про зменшення числа протизапальних T-регуляторних клітин, або про зниження їх супресорної активносmi.

Ключові слова: ВІЛ-інфекція, туберкульоз, $C D 4^{+} T$ лімфроцити, інтерлейкін-4, інтерферон-у, цитокіни.

\section{Відомості про авторів:}

Москалюк Василь Деонізійович, професор кафредри внутрішньої медицини та інфекційних хвороб, д. мед. н., просресор, ВДНЗУ «Буковинський державний медичний університет», м. Чернівці, Україна; e-mail: vdmoskaliuk@ ukr.net

ORCID: 0000-0002-4104-8153
Колотило Тетяна Романівна, асистентка кафедри внутрішньої медицини та інфекційних хвороб, ВДНЗУ «Буковинський державний медичний університет», м. Чернівці, Україна; e-mail: taniakolotylo15@gmail.com

ORCID: 0000-0002-0821-7904

Information about the authors:

Moskaliuk V.D. - MD, Professor of the Department of Internal Medicine and Infectious Diseases, Bukovynian State Medical University, Chernivtsi, Ukraine; e-mail: vdmoskaliuk@ ukr.net

ORCID: 0000-0002-4104-8153

Kolotylo T.R. - assistant of the Department of Internal Medicine and Infectious Diseases, Bukovynian State Medical University, Chernivtsi, Ukraine; e-mail: taniakolotylo15@gmail. com

ORCID: 0000-0002-0821-7904

Конорлікту інтересів немає.

Authors have no conflict of interest to declare.

Отримано 22.02.2021 р. 